MARKETINGOVÁ KOMUNIKACE VE ZDRAVOTNICTVÍ JAKO JEDNA ZE SLOŽEK C-MIXU

\title{
MARKETING COMMUNICATION IN HEALTH CARE AS ONE OF THE COMPONENTS OF C-MIX
}

Jana Bellová

Ústav sociálního lékařství a zdravotní politiky, Lékařská fakulta, Univerzita Palackého v Olomouci

\section{Abstrakt}

Tato teoretická studie se zabývá kategorizací typů komunikace ve zdravotnictví jakožto jednou ze stěžejních složek marketingového C-mixu. Ten tvoří základ marketingové strategie daného zdravotnického zařízení, která je pro jeho fungování v tržním prostředí či v prostředí smíšené ekonomiky nezbytná. Jednotlivé kategorie komunikace $v$ rámci zdravotnického zařizení je proto třeba charakterizovat, porozumět jejich významu a na základě tohoto je pak strategicky řídit.

\section{Abstract}

This theoretical study deals with the categorization of types of communication in health care as one of the major parts of C-mix. That is the base for marketing strategy of the health care providing institution in question that is crucial for functioning in open market economy as well as in mixed economy. It is therefore necessary to characterize the individual communication categories within the health care providing institution, understand their importance and based on that manage them strategically. 


\section{Klíčová slova}

marketingový C-mix, komunikace v rámci zdravotnického zařízení, pacient

\section{Key words}

marketing c-mix, communication within the health care providing institution, patient

\section{Úvod}

Lidé velmi vnímají problematiku péče o zdraví, problematiku zdravotnictví. Preference obyvatelstva ke zdravotnictví vykazují vysoký stupeň priorit, vnímání a citlivých postojů. (Zlámal, Bellová, 2005, s. 18) Zdravotnické zařízení působící $\mathrm{v}$ tomto prostředí na tento fakt musí adekvátně reagovat a přizpůsobit se mu. Je to důsledkem specifického postavení zdravotnictví v systému národního hospodářství a hlavních rysů, které jej odlišují od jiné sféry lidské činnosti. Tím je především to, že zdravotnictví se dotýká každého z lidí, každý je potenciální pacient. Ve středu zájmu stojí pacient, který je vstupem a výstupem systému poskytování zdravotní péče. Jeho celková spokojenost je primárním cílem každého zdravotnického zařízení. Proto otázka specifikace produktu ve zdravotnictví $z$ hlediska marketingu umožňuje lépe zacílit marketing daného zdravotnického zařízení a vytvořit tak přesnější marketingovou strategii. Ta pak koresponduje s celkovou strategií zdravotnického zařízení, v jejímž centru stojí spokojený pacient.

Pro vytvoření takovéto marketingové strategie je třeba vycházet z marketingového mixu. Marketingovým mixem zdravotnického zařízení rozumíme řízení hodnot, které jsou 
nabízeny, a který dostal postupně podobu současného C-mixu. (Exner et al., 2005, s. 54-55)

Komunikace je jednou ze složek C-mixu a její optimalizace, tedy maximální vzájemná kooperace všech jejích součástí na všech úrovních, je základem úspěšného strategického marketingového mixu, a tím i jedním z kroků vedoucích k naplnění cíle a poslání zdravotnického zařízení.

\section{Metodika}

Tato teoretická studie byla vypracována na základě deskripce marketingového $\mathrm{C}$-mixu a marketingové komunikace $\mathrm{V}$ rámci zdravotnického zařízení, jako jedné ze čtyř složek tohoto mixu. Použitou metodou bylo studium a následná kompilace rešerše českých a v českém jazyce publikovaných zahraničních monografí́.

\section{Text práce}

Dlouhodobá prosperita zdravotnického zařízení v ekonomice, at̉ již smíšené anebo tržní, je úzce spjata se spokojeností pacientů s poskytovanými službami. Uspokojení tohoto požadavku pak ústí do nutnosti neustálého monitoringu spokojenosti pacientů, at’ již reálných anebo potenciálních, a to v několika oblastech. Jedná se především o sledování přání pacienta, jeho hodnocení Činností poskytovaných zdravotnickým zařízením, sledováním toho, co mu pomáhá a brání překonávat zdravotní potíže a dalších.

Dle Exnera et al. (2005, s. 54, 167) sledování těchto aspektů pak vyústilo do tvorby C-mixu, který tvoří:

1. Convenience (pohodlí při předávání služby)

2. Communication (komunikace) 
3. Customer Values (zákaznické hodnoty)

4. Costs (náklady)

Podíváme-li se na C-mix očima posloupnosti dějů, které se v něm uplatňují, dostáváme následující (Exner et al., 2005, s. 55$)$ :

- Na začátku je vytvoření hodnoty ve formě služby •

- Následuje komunikace o povaze této hodnoty.

- Dochází k přímému předání této hodnoty.

- Realizuje se směna.

Svým způsobem je tedy C-mix určitým cyklem, ve kterém se snažíme postupně maximalizovat jeho jednotlivé složky, abychom na konci vytvořili takovou hodnotu, za kterou je pacient ochoten adekvátně zaplatit. Hodnotou pro pacienta není jen kategorie customer values (např. lékařský zákrok), ale svoji samostatnou hodnotu mají i kvalita komunikace, způsob jejich předávání a hodnota nákladů na ně. Tím dostává C-mix svoji hodnotovou povahu ve všech svých částech, každá z nich se dá řídit samostatně, s cílem jejich společné optimalizace. A přitom se zároveň řídí i výše celkové hodnoty. Kotler et al. (2007, s. 71) definuje komunikaci jako činnosti, které sdělují vlastnosti produktu a jejich přednosti klíčovým zákazníkům a přesvědčují je o nákupu. Avšak díky specifičnosti zdravotnictví jako odvětví Činnosti národního hospodářství a míre regulace výkonu činností v jeho rámci poskytovaných, je specifická $i$ oblast marketingové komunikace ve zdravotnictví a komunikace $\mathrm{V}$ rámci zdravotnického zařízení. Komunikace v rámci zdravotnického zařízení, tedy spolu s ostatními částmi C-mixu, tvoří jednu ze stěžejních oblastí marketingové strategie zdravotnického zařízení. Pacienti velmi silně 
vnímají způsob, jak se s nimi jedná, jak jsou informováni, jak se dovídají o možnostech, alternativách léčby, co znamenají různé naměřené laboratorní hodnoty, jaká rizika podstupují. Podíváme-li se tedy na oblast komunikace v rámci zdravotnického zařízení, jakožto jednu ze složek C-mixu, lze specifikovat několik oblastí. Dle Strnada (2003, s. 354) komunikace ve zdravotnictví probíhá na nejrůznějších úrovních a mezi nejdůležitější typy patří:

- komunikace mezi zdravotnickými pracovníky a pacienty

- komunikace mezi managementem zdravotnických zařízení a jeho pracovníky

- komunikace mezi managementem organizace a reprezentanty ostatních účastníků zdravotní péče

- komunikace s médii.

Tyto vybrané oblasti komunikace v rámci zdravotnického zařízení lze charakterizovat následujícím způsobem:

\section{Komunikace mezi zdravotnickými pracovníky a pacienty}

Dle Foreta (2006, s. 15) nejúčinnějším zpiosobem komunikace pořád zůstává osobní rozhovor. Způsob komunikace mezi zdravotnickými pracovníky a pacienty je tedy pro zdravotnické zařízení stěžejní. Jedná se o základní způsoby jednání a chování zdravotnického personálu vưči pacientovi, předávání a sdělování informací a podobně. Nejedná se však pouze - komunikaci verbální, ale také o komunikaci nonverbální. Dle Venglářové a Mahrové (2006, s. 40) ve zdravotnické praxi budou projevy neverbální komunikace velmi významné. Potřeba dorozumění je zde velká, stejně tak jako navázání vzájemné důvěry. V těchto situacích se objevuje řada neverbálních interakcí. Neverbální chování však nechápeme jako zcela 
oddělené, odehrávající se kdesi v pozadí. Mluvení a jednání probíhá současně. Komunikace je celek a mluvíme v ní slovy, tělem a činy.

Principy jednání a komunikace s pacienty jsou legislativně a normativně zakotveny. Etické kodexy jsou systematicky zpracovaným souborem norem a předpisů, který vymezuje a upravuje vztahy mezi členy určité komunity. Mají charakter normativních dokumentů, které upravují obecná i konkrétní pravidla práce v jednotlivých profesích. Pro oblast komunikace mezi zdravotnickými pracovníky a pacienty jsou to Etický kodex sester, Etický kodex ČLK, Etický kodex ČSK, Etický kodex fyzioterapeuta, Etický kodex Lékárníka a Etický kodex práv pacientů. Z legislativního upravení této problematiky je třeba zmínit především Listinu základních práv a svobod, která je součástí Ústavy České republiky, zákon Č. 20/1966 Sb., o péči - zdraví lidu, Trestní zákon Č. 140/1961 Sb., Či veškerá právní úprava o povinné mlčenlivosti zdravotnických i nezdravotnických pracovníků.

Pro oblast managementu a řízení této sféry marketingové komunikace plyne potřebný důraz na řízení komunikace. Do popředí se v současné době dostává otázka použití komunikačního auditu zdravotnického zařízení, jakožto managerského nástroje sloužícího $k$ měření úplnosti a kvality komunikace mezi pacientem a pracovníky zdravotnického zařízení. Pro provedení auditu tohoto typu lze použít komerční firmy zabývající se přímo strategickým managementem pro zdravotnické subjekty. 
Komunikace mezi managementem zdravotnických zařízení a jeho pracovníky

Důležité pro řízení marketingové komunikace v rámci zdravotnického zařízení je také řízení této oblasti komunikace. Ta je důležitou součástí celého motivačního systému. Při jejím efektivním fungování vytváří velmi potřebnou a spolehlivou zpětnou vazbu a slouží tak jako autoregulační prvek celého systému. Pracovníci se stávají zainteresovaní na chodu celé organizace a tím se podílejí na jejím řízení, jejich námitky a připomínky jsou vítány, respektovány a zakomponovány do činnosti celé organizace, fungování celého zdravotnického zařízení. Stává se účinným motivujícím mechanismem lidské činnosti, avšak při jejím podcenění či nerespektování její důležitosti, se naopak stává příčinou selhání dalšího rozvoje, příčinou stagnace a často i důvodem $k$ nespokojenosti, jak pracovníki̊, tak ve finální podobě i pacientů.

Pro management tedy představuje nezbytnou zpětnou vazbu, pro zaměstnance představuje důležitý prvek zájmu o jejich práci ze strany managementu. Pro management zdravotnického zařízení existují v této oblasti velké rezervy a je třeba si uvědomit, že naplnění cíle zdravotnického zařízení lze dosáhnout pouze při plné, dobrovolné a motivované participaci všech pracovníků na všech funkčních pozicích.

\section{Komunikace mezi managementem organizace a reprezentanty} ostatních účastníků zdravotní péče

Zdravotnické zařízení musí adekvátním způsobem komunikovat se všemi ostatními účastníky zdravotní péče. Mezi tyto účastníky patří řada dalších subjektů, jsou to další lékaři a zdravotničtí pracovníci, distributoři, zdravotní pojištovny, 
profesní organizace zdravotníků, orgány státní správy a samosprávy a další. Jedná se tedy o komunikaci zdravotnického zařízení navenek, komunikaci vnější. Řízení této oblasti komunikace je často velmi náročné, protože se často jedná o snahy hledání společného kompromisu, tedy míry ustoupení na obou stranách.

\section{Komunikace s médii}

Komunikace s médii označuje řadu komunikačních aktivit zdravotnického zařízení a má dle Strnada (2003, s. 355) velký význam pro vytváření určitého obrazu příslušného zdravotnického zařízení. Jedná se o vnější formu komunikace, prezentuje zdravotnické zařízení navenek, pomáhá utvářet celkový obraz o daném zdravotnickém zařízení, jeho aktivitách a činnostech v rámci něho probíhajících. Způsob a komunikace s médii se odvíjí především od velikosti zdravotnického zařízení. Velká zdravotnická zařízení mají pro komunikaci s médii ustanoveného tiskového mluvčího, na kterého je delegována veškerá práce s médii. Média si zvyknou obracet se vždy na jednoho člověka, a ten bude mít dostatek času a prostoru vybudovat si s médii a jednotlivými novináři dobré pracovní vztahy. Tiskový mluvčí se tak stává tváří zdravotnického zařízení, které prostřednictvím komunikace s médii komunikuje se širokou veřejností. Na druhou stranu řada zdravotnických zařizení postupně zavádí pozici ombudsmana, jehož funkce vznikla proto, aby chránil práva pacientů a reagoval na jejich podněty k řešení. Stává se prostředníkem pro komunikaci mezi veřejností, pacienty a jejich příbuznými a zdravotnickým zařízením. Tato pozice sice nemá doposud dlouhodobé trvání, lze v ní však spatřovat novou formu autoregulační zpětné vazby systému zdravotnictví, 
kde vstupem je pacient, lékař a jeho vědomosti, znalosti, čas a finanční prostředky. Procesem je poskytování zdravotnické péče, a výstupem je v ideálním případě spokojený pacient. Z tohoto pojetí se dá na ombudsmana nahlížet jako na autoregulační prvek systému, jehož cílem je spokojenost pacienta a potažmo zlepšení zdravotního stavu celé populace, sloužící konkrétnímu zdravotnickému zařízení.

\section{Závěr}

Pod pojmem komunikace zdravotnického zařizení se rozumí relativně široká škála komunikativních prvků, a to od nonverbální komunikace přijímacího personálu zdravotnického zařízení, až po výroční zprávu daného zařízení. Podstatná je unifikace všech těchto složek a kvalitní strategické řízení komunikace zdravotnického zařízení jako celku, jehož cílem je spokojený pacient.

Zdravotnické zařízení, pokud má dosáhnout tohoto cíle, musí být strategicky řízeno. Součástí strategického řízení je komplexní řízení všech marketingových složek, tedy celého C-mixu. Ľízení komunikace v rámci zdravotnického zařízení a jednotlivá koordinace všech jejích složek je tedy nedílnou součástí činností managementu.

\section{Seznam bibliografických odkazů}

EXNER, L., RAITER, T., STEJSKALOVÁ, D. 2005. Strategický marketing zdravotnických zařízení. 1.vyd. Praha: Professional Publishing, 2005. 188 s. ISBN 80-86419-73-8.

FORET, M. 2006. Marketingová komunikace. 1.vyd. Brno: Computer Press, 2006. 464 s. ISBN 80-251-1041-9. 
KOTLER, P. et al. 2007. Moderní marketing: 4. evropské vydání. 1.vyd. Praha: Grada Publishing, a.s., 2007. 1048 s. ISBN 97880-247-1545-2.

STRNAD, L. 2003. Marketing ve zdravotnictví. In GLADKIJ, I. et al. Management ve zdravotnictví. 1.vyd. Brno: Computer Press, 2003. 380 s. ISBN 80-7226-996-8.

VENGLÁŘOVÁ, M., MAHROVÁ, G. 2006. Komunikace pro zdravotní sestry. 1.vyd. Praha: Grada publishing, a.s., 2006. 144 s. ISBN $80-247-1262-8$.

ZLÁMAL, J., BELLOVÁ, J. 2005. Ekonomika zdravotnictví. 1.vyd. Brno: NCO NZO, 2005. 206 s. ISBN 80-7013-429-1.

\section{Kontakt na autora:}

Ing. Jana Bellová

Ústav sociálního lékařství a zdravotní politiky

Lékařská fakulta, Univerzita Palackého v Olomouci

Hněvotínská 3

CZ-775 15 OLOMOUC

little_chiefeseznam.cz 